\title{
Eugenol and Its Liposomal Based Nano-carrier Protects Against Anxiety Disorder in Mice.
}

fahad jibran siyal ( $\square$ fahad_jibran_hbk@hotmail.com )

Shaheed Montarma Benazir Bhutto Medical University https://orcid.org/0000-0003-0318-6659

rehan ahmed siddiqui

Ziauddin University

zahida memon

Ziauddin University

zahra batool

Dr Panjwani Center for Molecular Medicine and Drug Research

aneela Atta Ur Rahman

Liaquat University of Medical and Health Sciences

arsalan humayun

Shaheed Mohtarma Benazir Bhutto Medical university

Research

Keywords: Nanoparticles, Anxiety, Open Field Test, Elevated Plus Maze Test, eugenol

Posted Date: October 29th, 2021

DOl: https://doi.org/10.21203/rs.3.rs-985817/v1

License: (c) (i) This work is licensed under a Creative Commons Attribution 4.0 International License.

Read Full License 


\section{Abstract}

Background: Anxiety can also be termed as excessive worry which last for at least more than six months and patients can have difficulty in controlling them. Anxiety is having $31 \%$ of life time prevalence and sad part is that the anxiety disorders are not treated and diagnosed well. $3.1 \%$ which is 6.8 Million peoples of America are having anxiety disorders. The main part of clove oil is eugenol along with caryophyllene. Eugenol is present at about 70 to 90 percentage and also it contains 15 percentage of total dry weight of bud.

Methodology: Pre-clinical experimental study was conducted for 10-12 Months. Male BALB/c mice were purchased from ICCBS. Sample Size was 42 BALB/c mice and divided into 07 groups.

Results: The animal model was developed and it was found that Eugenol and its liposomal based nano carrier protect anxiety disorders in mice with the help of behavioral tests such as Elevated plus maze and open field tests and was recorded as Mean and SD, frequency and percentages accordingly.

Conclusion: Therefore with the help of behavioral studies i.e. open field test and elevated plus maze test, eugenol and its liposomal based nano particle protect anxiety disorder in the mice by increasing the entry time and stay of mice in open arms for longer duration in elevated maze plus test and in open field the anxiety was reduced after mice spent most of time in the center rather than periphery.

\section{Introduction}

Anxiety can also be termed as excessive worry which last for at least more than six months and patients can have difficulty in controlling them. Anxiety can also cause physical impairment or distress in important areas of functioning. Sometimes the phrase GAD incorrectly refers that the symptoms can be overall nonspecific. In the 5th volume of the "Diagnostic \& Statistical Manual of Medical Disorders" the newest terminology generalized worry disorder was considered but it was not adopted (American Psychiatric Association., 2013). There is rare reporting from patients regarding worry symptom. The most predominant physical symptoms which patients report at primary care settings are gastrointestinal distress or headache (Stein et al., 2005). In children, GAD often displays as frequent abdominal pain etc. Major depression coexists with them, although it is very hard to distinguish it from GAD. For example insomnia and fatigue are the symptoms which occur in both disorders. Patients with GAD mostly suggest a sense of helplessness; in contrast the patient of major depression feels hopeless. Nevertheless the patients suffering from GAD are at the increased risk of suicide and deliberate self-harm (Chartrand et al., 2012). Anxiety is having $31 \%$ of life time prevalence and sad part is that the anxiety disorders are not treated and diagnosed well (Katzman et al., 2014). 3.1\% which is 6.8 Million peoples of America are having anxiety disorders (Mousa et al., 2016).About 25\% of United Stated population is suffering from anxiety disorders. Anxiety (Pathological) is the most frequent mental \& psychological disorder which 6 leads to suffering of routine life (Hasanpour-Dehkordi, 2016).About 35 percentages of peoples with GAD medicate with drugs and alcohols to decrease anxiety related signs and this causes increased risk of 
drugs and alcohol abuse (Robinson J, et al., 2011).Treatment currently used for anxiety disorders are "serotonin-noradrenaline reuptake inhibitors (SNRIs) ", "serotonin reuptake inhibitors (SSRIs)", hydroxyzine, phenelzine, buspirone, moclobemide, benzodiazepines, pregabalin and tricyclic antidepressants and opipramol (Bandelow et al., 2015).

The Clove oil is used since ancient times and it is used as an antimicrobial, antiseptic and antispasmodic agent in Chinese traditional medicine. Currently eugenol is used in household products, pharmaceutical products, cosmetics and dental products, fragrance in soaps, flavoring substance for food and skin care products (Nejad et al., 2017). The main part of clove oil is eugenol along with caryophyllene (Malik et al., 2016). Eugenol is present at about 70 to 90 percentage and also it contains 15 percentage of total dry weight of bud (Galal and Abdellatief, 2015).In recent times majority of people are looking to use medicinal plants, native \& folk medicine along with their derived products to treat diseases (Nikfarjam et al., 2016). Medicinal plants have one or more organs; they also contain effective compounds along with contain therapeutic effects (Parsaei, 2016; Asadi-Samani, 2015; Bahmani, 2016). The Clove oil is used since ancient times and it is used as an antimicrobial, antiseptic and antispasmodic agent in Chinese traditional medicine. Currently eugenol is used in household products, pharmaceutical products, cosmetics and dental products, fragrance in soaps, flavoring substance for food and skin care products (Nejad et al., 2017).The main part of clove oil is eugenol along with caryophyllene (Malik et al., 2016). Eugenol is present at about 70 to 90 percentage and also it contains 15 percentage of total dry weight of bud (Galal and Abdellatief, 2015).In recent times majority of people are looking to use medicinal plants, native \& folk medicine along with their derived products to treat diseases (Nikfarjam et al., 2016). Medicinal plants have one or more organs; they also contain effective compounds along with contain therapeutic effects (Parsaei, 2016; Asadi-Samani, 2015; Bahmani, 2016).

\section{Methodology}

2.1 STUDY DESIGN: Pre-clinical experimental study

\subsection{DURATION OF THE STUDY: 10-12 Months}

2.3 ANIMALS: Male BALB/c mice were purchased from ICCBS. Sample Size were 42 BALB/c mice, divided into 07 groups.

\subsection{INCLUSION CRITERIA:}

- Male BALB/c mice

- Weighing 20-30 gm (Adult).

- No co morbidity

\subsection{EXCLUSION CRITERIA}

- Male mice weighing less than $20 \mathrm{gm}$ or more than $30 \mathrm{gm}$. 
- All female mice were excluded due to hormonal level which might cause data variability from estrous cycles.

2.6 GROUPING OF ANIMALS: Animals were placed into subsequent groups with six animals per group:

- Group I: (Vehicle control) Animals were given Normal Saline, per oral

- Group II: (Anxiety Group) Animals were given Chronic restraint stress and Normal Saline, per oral

- Group III: (Treatment Group) Animals were given Chronic restraint stress and Eugenol, 50 mg/kg, per oral

- Group IV: (Treatment Group) Animals were given Chronic restraint stress and Eugenol, $100 \mathrm{mg} / \mathrm{kg}$, per oral

- Group V: (Treatment Group) Animals were given Chronic restraint stress and EUGVes or Eug-lypo 15 $\mathrm{mg} / \mathrm{kg}$, per oral

- Group Vl: (Treatment group) Animals were given Chronic restraint stress and EUGVes or Eug-lypo 30 $\mathrm{mg} / \mathrm{kg}$, per oral Group

- Group VII: (Treatment group) Animals were given Chronic restraint stress and Diazepam, $01 \mathrm{mg} / \mathrm{kg}$, per oral

2.7 HOUSING OF ANIMALS: BALB/c mice were maintained and kept in the animal house facility of Faculty of Pharmacy, Ziauddin University Karachi. Animals were given free access to water and rodent chow in their conventional cages kept at $22-23^{\circ} \mathrm{C}$ with 12-hr light-dark cycle. Prior to the start of experiment, animals were acclimatized with the experimenter and the environment for few days.

2.8 CONVENTIONAL RESTRAIN MODEL: it was done in accordance with the protocol mentioned in (Siyal et al., 2020).

2.9 SYNTHESIS: The synthesis was done in accordance with the protocol mentioned in (Siyal et al., 2020).

\section{Behavioral Tests}

- ELEVATED PLUS MAZE: It is built with grey colored woody planks. Compromising of two open arms, 10 (cm in width) x 50 (cm in length) along with 02 arms enclosed, 40 (cm in height) $\times 10$ (cm in width) $\times 50 \mathrm{~cm}$ (length) enclosed by a portable lid, in order that the both arms (closed and open) were opposite The maze was inflated to an altitude of $50 \mathrm{~cm}$ against the floor. In the 5-min test time, the subsequent measurements were taken: the no of entry in the both arms and the time consumed in the both arms. An entry was defined as all 4 feet into one arm. The increase in open arm entry along with increase in time spent in open arms revealed the anxiolytic activity because mice normally like the closed arms (Komada, Takao and Miyakawa, 2008).

- OPEN FIELD TEST: Spontaneous exploratory and locomotor activity was checked in open field (the

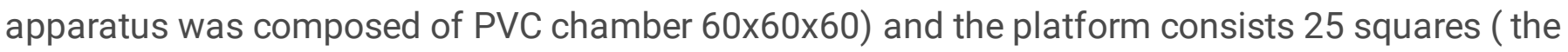


centre containing nine and periphery containing 16) surrounded by a wall. The animals were located in the intermediate or centre of the arena and the animal were recorded with a webcam for 5 min.

The videos were later visualized and the periphery versus centre distance travelled would determine to assess anxiolytic behavior (Ali et al., 2019).

\section{Statistical Analysis}

Data was analyzed by MS Excel 2010, Numerical variables were represented as means and standard deviation (SD) and categorical variables were presented as frequency and percentages. Appropriate test of significance was applied (ANOVA Single factor and by t-test). $p$ value $<0.05$ was considered statistically significant.

\section{Results}

- ELEVATED PLUS MAZE: Figure 1 showed the mean value for stay in Open arm regarding Normal group as $190.83 \pm 44.10$ seconds (s) (Mean \pm SD). The mean value for Eug 50+ANX was $195.5 \pm$ $23.40 \mathrm{~s}(\mathrm{p}<0.01)$, for EUG $100+$ ANX the mean value was $199.66 \pm 23.20 \mathrm{~s}(\mathrm{p}<0.01)$, regarding EugLypo15+ ANX it was $196 \pm 12.79 \mathrm{~s}(\mathrm{p}<0.01)$ along with the mean value for Eug-lypo $30+$ ANX was $202 \pm 20.77 \mathrm{~s}(\mathrm{p}<0.01)$ when compared with anxiety group it was $50.16 \pm 52.90 \mathrm{~s}(\mathrm{P}<0.001)$ and diazepam was used as reference drug having mean value of $191.66 \pm 44.88 \mathrm{~s}(\mathrm{p}<0.01)$ (Table 1). The Mean value for stay in Close arm regarding for Normal group was about $101.66 \pm 40.93 \mathrm{~s}$. The mean value for Eug $50+A N X$ was $84.16 \pm 27.89 \mathrm{~s}(\mathrm{p}<0.01)$ for EUG $100+$ ANX the mean value was 82 $\pm 23.91 \mathrm{~s}(\mathrm{p}<0.01)$. The mean value for Eug-Lypo15 + ANX was $87.66 \pm 8.80 \mathrm{~s}(\mathrm{p}<0.01)$ along with the mean value for Eug-lypo 30+ ANX was $81 \pm 15.21 \mathrm{~s}(\mathrm{p}<0.01)$ when compared with anxiety group it was $217 \pm 60.53 \mathrm{~s}(P<0.01)$ and diazepam was used as reference drug having mean value of $93.16 \pm$ $44.64 \mathrm{~s}(\mathrm{p}<0.01)$. (Table 2). As per figure 2, the Mean for Open arm entries of Normal group was 9.33 \pm 1.50 seconds (s) (Mean $\pm S D$ ). The mean value for Eug $50+A N X$ was $10.5 \pm 1.76 \mathrm{~s}(\mathrm{p}<0.001)$, for EUG $100+$ ANX it was $11.33 \pm 2.25 \mathrm{~s}(\mathrm{p}<0.001)$, for Eug-Lypo 15+ANX it was $10.33 \pm 1.75 \mathrm{~s}$ ( $\mathrm{p}$ $<0.001)$ and for Eug-Lypo 30+ANX it was $12 \pm 2.36 \mathrm{~s}(\mathrm{p}<0.001)$ when compared with anxiety group it was $4.33 \pm 0.51 \mathrm{~s}(\mathrm{p}<0.001)$, and diazepam was used as reference drug having mean value of 10.16 $\pm 2.31 \mathrm{~s}(\mathrm{p}<0.001)$ (Table 3). The Mean for Close arm entries for Normal group was $6.33 \pm 1.03 \mathrm{~s}$. The mean values for Eug 50+ANX was $8 \pm 1.41 \mathrm{~s}(\mathrm{p}<0.001)$, for EUG 100+ANX it was $8.66 \pm 1.50 \mathrm{~s}$ $(p<0.001)$, regarding Eug-Lypo 15+ANX it was $8.33 \pm 1.63 \mathrm{~s}(\mathrm{p}<0.001)$, for Eug-Lypo 30+ANX it was

$8.66 \pm 1.96 \mathrm{~s}(\mathrm{p}<0.001)$ when compared to anxiety it was $3.33 \pm 0.51 \mathrm{~s}(\mathrm{p}<0.001)$, and diazepam was used as reference drug having mean value of $7.33 \pm 1.50 \mathrm{~s}(\mathrm{p}<0.001)$ ( Table 4$)$. 
Table 1

Elevated Plus Maze showing Mean and SD regarding open arm

\begin{tabular}{|lccccccc|}
\hline Open Arm & Normal & Anxiety & $\begin{array}{l}\text { Eug 50 } \\
+ \text { ANX }\end{array}$ & $\begin{array}{l}\text { Eug } \\
\mathbf{1 0 0}\end{array}$ & $\begin{array}{l}\text { Eug- } \\
\text { lypo } \\
\text { + } 5+\end{array}$ & $\begin{array}{l}\text { Eug- } \\
\text { lypo } \\
\text { 30+ } \\
\text { ANX }\end{array}$ & Diazepam \\
\hline $\begin{array}{l}\text { Mean } \\
\text { (seconds) }\end{array}$ & 190.83 & 50.16 & 195.5 & 199.66 & 196 & 202 & 191.66 \\
$\begin{array}{l}\text { Standard } \\
\text { Deviation } \\
\text { (SD) }\end{array}$ & 44.10 & 52.90 & 23.40 & 23.20 & 12.79 & 20.77 & 44.88 \\
$\begin{array}{l}\text { P value (Paired } \\
\text { t-test) }\end{array}$ & & $<0.001$ & $<0.001$ & $<0.001$ & $<0.001$ & $<0.001$ & $<0.001$ \\
\hline
\end{tabular}

Table 2

Elevated Plus Maze showing Mean and SD regarding close arm

\begin{tabular}{|lccccccc|}
\hline Close Arm & Normal & Anxiety & $\begin{array}{l}\text { Eug } \\
\text { 50+ } \\
\text { ANX }\end{array}$ & $\begin{array}{l}\text { Eug } \\
\text { 100+ANX }\end{array}$ & $\begin{array}{l}\text { Eug- } \\
\text { lypo } \\
\text { 15+ } \\
\text { ANX }\end{array}$ & $\begin{array}{l}\text { Eug- } \\
\text { lypo+ANX } \\
\text { 30+ANX }\end{array}$ & Diazepam \\
\hline $\begin{array}{l}\text { Mean } \\
\text { (seconds) }\end{array}$ & 101.66 & 217 & 84.16 & 82 & 87.66 & 81 & 93.16 \\
$\begin{array}{l}\text { Standard } \\
\text { Deviation } \\
\text { (SD) }\end{array}$ & 40.93 & 60.53 & 27.89 & 23.91 & 8.80 & 15.21 & 44.64 \\
\hline $\begin{array}{l}\text { P value } \\
\text { (Paired t- test) }\end{array}$ & & $<0.01$ & $<0.01$ & $<0.01$ & $<0.01$ & $<0.01$ & $<0.01$ \\
\hline
\end{tabular}

Table 3

Mean and SD regarding open arm entries in Elevated Plus Maze

\begin{tabular}{|llllllll|}
\hline $\begin{array}{l}\text { Open Arm } \\
\text { (entries) }\end{array}$ & Normal & Anxiety & $\begin{array}{l}\text { Eug } \\
50+ \\
\text { ANX }\end{array}$ & $\begin{array}{l}\text { Eug100 } \\
+ \text { ANX }\end{array}$ & $\begin{array}{l}\text { Eug-lypo } \\
15+ \\
\text { ANX }\end{array}$ & $\begin{array}{l}\text { Eug-lypo } \\
\begin{array}{l}\text { ANX } \\
\text { ANX }\end{array}\end{array}$ & Diazepam \\
\hline $\begin{array}{l}\text { Mean } \\
\text { (seconds) }\end{array}$ & 9.33 & 4.33 & 10.5 & 11.33 & 10.33 & 12 & 10.16 \\
$\begin{array}{l}\text { Standard } \\
\text { Deviation } \\
\text { (SD) }\end{array}$ & 1.50 & 0.51 & 1.76 & 2.25 & 1.75 & 2.36 & 2.316607 \\
\hline $\begin{array}{l}\text { P value (Paired } \\
\text { t- test) }\end{array}$ & & $P<0.001$ & $P<0.001$ & $P<0.001$ & $P<0.001$ & $P<0.001$ & $P<0.001$ \\
\hline
\end{tabular}


Table 4

Mean and SD regarding close arm entries in Elevated Plus Maze.

\begin{tabular}{|llllllll|}
\hline $\begin{array}{l}\text { Close Arm } \\
\text { (entries) }\end{array}$ & Normal & Anxiety & $\begin{array}{l}\text { Eug } \\
\mathbf{5 0 +} \\
\text { ANX }\end{array}$ & $\begin{array}{l}\text { Eug } \\
\text { 100 }+ \\
\text { ANX }\end{array}$ & $\begin{array}{l}\text { Eug-lypo } \\
\mathbf{1 5 +} \\
\text { ANX }\end{array}$ & $\begin{array}{l}\text { Eug-lypo } \\
\text { 30+ ANX }\end{array}$ & Diazepam \\
\hline $\begin{array}{l}\text { Mean } \\
\text { (seconds) }\end{array}$ & 6.33 & 3.33 & 8 & 8.66 & 8.33 & 8.66 & 7.333333 \\
$\begin{array}{l}\text { Standard } \\
\text { Deviation } \\
\text { (SD) }\end{array}$ & 1.03 & 0.51 & 1.41 & 1.50 & 1.63 & 1.96 & 1.505545 \\
$\begin{array}{l}\text { P value } \\
\text { (Paired t-test) }\end{array}$ & & $<0.001$ & $<0.001$ & $<0.001$ & $<0.001$ & $<0.001$ & $<0.001$ \\
\hline
\end{tabular}

- OPEN FIELD TEST: The Figure 3 represents the Mean for Open field (Time in centre) of Normal group was $80.83 \pm 6.43$ seconds (s) (Mean \pm SD). The mean for Eug $50+A N X$ was $69.33 \pm 13.35 s(p<0.05)$. The open arm entry mean for EUG 100+ ANX was $71 \pm 3.52 \mathrm{~s}(\mathrm{p}<0.04)$, for Eug-Lypo 15+ANX it was $68.83 \pm 9.94 \mathrm{~s}(\mathrm{p}<0.05)$ regarding Eug-Lypo $30+A N X$ it was $107.16 \pm 25.27 \mathrm{~s}(\mathrm{p}<0.01)$, when compared with anxiety which group it was $43.83 \pm 23.48 \mathrm{~s}(\mathrm{p}<0.02)$. Diazepam was used as reference drug with mean $73.33 \pm 17.73 \mathrm{~s}(\mathrm{p}<0.04)$ (Table 5$)$. The mean for open filed (Time in periphery) for Normal group was $219.16 \pm 6.43 \mathrm{~s}$. the mean regarding Eug $50+A N X$ was $230.66 \pm 13.35 \mathrm{~s}(\mathrm{p}<0.05)$, for EUG 100+ ANX it was $229 \pm 3.52 \mathrm{~s}(\mathrm{p}<0.04)$, regarding Eug-Lypo 15+ANX it was $231.16 \pm 9.94 \mathrm{~s}$ $(p<0.05)$ and for Eug-Lypo 30+ANX it was $192.83 \pm 25.27 s(p<0.01)$ when compared with anxiety group it was $256.16 \pm 23.48 \mathrm{~s}(\mathrm{p}<0.02)$. Diazepam was used as reference drug with mean $226.66 \pm$ $17.73 \mathrm{~s}(\mathrm{p}<0.04)($ Table 6$)$.

Table 5

Mean and SD of centre in open field

\begin{tabular}{|lccccccc|}
\hline $\begin{array}{l}\text { Time in } \\
\text { centre }\end{array}$ & Normal & Anxiety & $\begin{array}{l}\text { Eug } \\
\text { 50+ANX }\end{array}$ & $\begin{array}{l}\text { EUG } \\
\text { 100+ } \\
\text { ANX }\end{array}$ & $\begin{array}{l}\text { Eug-Lypo } \\
\text { 15+ANX }\end{array}$ & $\begin{array}{l}\text { Eug-Lypo } \\
\text { 30+ANX }\end{array}$ & Diazepam \\
\hline $\begin{array}{l}\text { Mean } \\
\text { (Seconds) }\end{array}$ & 80.83 & 43.83 & 69.33 & 71 & 68.83 & 107.16 & 73.33 \\
\hline SD & 6.43 & 23.48 & 13.35 & 3.52 & 9.94 & 25.27 & 17.73 \\
\hline $\begin{array}{l}\text { P value } \\
\begin{array}{l}\text { (Paired t- } \\
\text { test) }\end{array}\end{array}$ & & $<0.02$ & $<0.05$ & $<0.04$ & $<0.05$ & $<0.01$ & $<0.04$ \\
\hline
\end{tabular}


Table 6

Mean and SD for time in periphery in open field

\begin{tabular}{|lccccccc|}
\hline $\begin{array}{l}\text { Time in } \\
\text { Periphery }\end{array}$ & Normal & Anxiety & $\begin{array}{l}\text { Eug } \\
\text { 50+ANX }\end{array}$ & $\begin{array}{l}\text { EUG } \\
\text { ANX+ } \\
\text { ANX }\end{array}$ & $\begin{array}{l}\text { Eug-Lypo } \\
\text { 15+ANX }\end{array}$ & $\begin{array}{l}\text { Eug-Lypo } \\
\text { 30+ANX }\end{array}$ & Diazepam \\
\hline $\begin{array}{l}\text { Mean } \\
\text { (seconds) }\end{array}$ & 219.16 & 256.16 & 230.66 & 229 & 231.16 & 192.83 & 226.66 \\
\hline SD & 6.43 & 23.48 & 13.35 & 3.52 & 9.94 & 25.27 & 17.73 \\
\hline $\begin{array}{l}\text { P value } \\
\text { (Paired t-test) }\end{array}$ & & $<0.02$ & $<0.05$ & $<0.04$ & $<0.05$ & $<0.01$ & $<0.04$ \\
\hline
\end{tabular}

\section{Discussion}

Our result suggests that with the help of conventional restrain stress animal model we were able to induce anxiety in the BALB/c mice. Each mouse was exposed to restraint and placed in a 50-ml conical tube (ventilated). They were restrained for five consecutive nights through period of each day i.e. restraint stress, from 17: $00 \mathrm{pm}$ to 09:00 am and one hour before conventional restrain stress they were given test compounds which is eugenol and its liposomal based nano carriers at different doses and then behavioral studies were carried out and by elevated plus maze test we found out that eugenol and its liposomal based nano carrier at different doses reduces anxiety by increasing the stay of mice in open arm for longer duration when compared with closed arms and also increase in the open arm entries when compared with close arm entries. The results of elevated plus maze indicate decrease in anxiety after receiving tests compounds because mice normally like to explore open arms when compared with anxiety group which was induced by conventional restrain stress method and our results were also statistical significant.

In one of previous study it was found that the changes in elevated plus maze behavior were brought about by ablation of Neurokinin 1 Receptor expressing neurons in amygdale causing increase in anxiety related behaviors. The amygdala is involved in anxiety especially in association of environmental stimuli with fearful events (Phillips and LeDoux, 1992). In comparison to our study during elevated maze plus test that in case of anxiety the mice remained for majority of time in close arm and when treated with eugneol and its liposomal based nano particle in dose dependent manner they remained in open arm for majority of time as discussed in our results which marks reduction in anxiety.

With the help of Open field test we also found out that eugenol and its liposomal based nano carriers at different doses reduces anxiety because mice normally like to move across centre and during anxiety they like to move along with periphery. Hence our results are suggestive of reduction in anxiety among treated groups when compared with anxiety group which was induced by conventional restrain stress method and our results were also statistical significant. 
Many herbal plants contain eugenol possessing many activities (Muller et al., 2006). In also found out that Eugenol and its liposomal based nanocarrier posses anti anxiety effects in dose dependent manner.

In traditional Practices, eugenol is also effective in reversing the short and long term memory (Halder et al., 2011). In our study we found out that eugenol and its liposomal based nanocarriers were useful in reducing anxiety at dose dependent manner.

In one of the study eugenol's various pharmacological effects were evaluated at $100 \mathrm{mg} / \mathrm{kg}$ dose with the help of animal model. To check the antinociceptive effects three models were used Viz Tail flick test, acetic acid induced writhing tests and hot plate tests. Eugenol showed significant effect $p=0.002$ in all of the three models and this effects was in accordance with previous studies.(Kurian et al., 2006) (Müller et al., 2006). In comparison to our study we used two behavioral tests of anxiety which were elevated maze plus and open field and assessed that eugenol and its liposomal based nano carrier in dose dependent manner reduced anxiety.

\section{Conclusion}

The animal model was developed to assess whether Eugenol and its liposomal based nano carrier protect anxiety disorders in mice or vice versa. Therefore with the help of behavioral studies i.e. open field test and elevated plus maze test, eugenol and its liposomal based nano particle protect anxiety disorder in the mice by increasing the entry time and stay of mice in open arms for longer duration in elevated maze plus test and in open field the anxiety was reduced after mice spent most of time in the center rather than periphery.

\section{LIMITATIONS OF STUDY:}

- Due to financial limitation, Westerns Blot couldn't be tested.

- By increasing sample size, more efficient could be obtained.

- Testing with other Anxiety models couldn't be done due unavailability of equipment's.

RECOMMENDATION: We recommend evaluating the further molecular mechanisms or pathways which causes reduction in anxiety; therefore this compound may be selected for clinical trials.

\section{Abbreviations}

SNRIs= serotonin-noradrenaline reuptake inhibitors

SSRIs= serotonin reuptake inhibitors

ANOVA $=$ analysis of variance

Eug 50+ANX =) Animals were given Chronic restraint stress and Eugenol, $50 \mathrm{mg} / \mathrm{kg}$ 
EUG $100+$ ANX= Animals were given Chronic restraint stress and Eugenol 100 mg/kg,

Eug-Lypo15+ ANX = Animals were given Chronic restraint stress and EUGVes or Eug-lypo 15 mg/kg

Eug-lypo 30 + ANX = Animals were given Chronic restraint stress and EUGVes or Eug-lypo $30 \mathrm{mg} / \mathrm{kg}$

\section{Declarations}

The author does not have any conflict of interest

Ethics approval and consent to participate: Ethical endorsement was taken from Animal Ethical Committee (AEC) of Ziauddin University (Protocol No. 2019-004).

Consent to publish: the authors give consent to publish the above mentioned study.

Availability of data and materials: can be provided if required.

Competing interests: The author doesn't have any competing interests.

Funding: this project was self-funded

Authors' Contributions:: FJS generated the idea conducted the study, RAS and ZM formulated the study. ZB and AAR helped in statistics, AH helped in literature survey.

Acknowledgements: we are thankful to Ziauddin University, Karachi, faculty of for their support in conduction of above mentioned study.

\section{References}

1. ahmani M, Tajeddini P, Ezatpour B, Rafieian-Kopaei M, Naghdi N, AsadiSamani M. Ethenobothanical study of medicinal plants against parasites detected in Shiraz, southern part of Iran. Der Pharm Lettre. 2016;8(1):153-60.

2. Ali MM, Baig MT, Aslam M, Ibrahim S, Jabeen A, Shaikh S, ... Rawat A. In-vivo study on anxiolytic effects of hydroalcoholic extract of Agaricus blazei Murill. International Journal of Medical Research Health Sciences. 2019;8(8):70-4.

3. American Psychiatric Association. Diagnostic and statistical manual of mental disorders (DSM-5®). American Psychiatric Pub; 2013.

4. Asadi-Samani M, Kafash-Farkhad N, Azimi N, Fasihi A, Alinia-Ahandani E, Rafieian-Kopaei M. Medicinal plants with hepatoprotective activity in Iranian folk medicine. Asian Pac J Trop Biomed. 2015;5(2):146-57.

5. Bandelow B, et al. „Efficacy of treatments for anxiety disorders: A meta-analysis $₫$. Int Clin Psychopharmacol. 2015;30(4):183-92. 
6. Chartrand H, Sareen J, Toews M, Bolton JM. Suicide attempts versus nonsuicidal self- injury among individuals with anxiety disorders in a nationally representative sample. Depress Anxiety. 2012;29(3):172-9.

7. Galal AA, Abdellatief SA. Neuropharmacological studies on Syzygium aromaticum (clove) essential oil. International Journal of Pharma Sciences. 2015;5(2):1013-8.

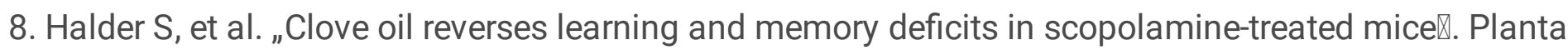
Med. 2011;77(8):830-4.

9. Hasanpour-Dehkordi A, Solati K. The efficacy of three learning methods collaborative, context-based learning and traditional, on learning, attitude and behaviour of undergraduate nursing students, Integrating theory and practice. Journal of Clinical Diagnostic Research. 2016;10(4):1-4.

10. Katzman MA, et al. „Canadian clinical practice guidelines for the management of anxiety, posttraumatic stress and obsessive-compulsive disorders $\llbracket$. BMC Psychiatry. 2014;14(SUPPL.1):183.

11. Komada M, Takao K, Miyakawa T. (2008). Elevated plus maze for mice. JoVE (Journal of Visualized Experiments), (22), e1088.

12. Kurian R, Arulmozhi DK, Veeranjaneyulu A, Bodhankar SL. Effect of eugenol on animal models of nociception. Indian Journal of Pharmacology. 2006;38(5):341.

13. Malik K, Bashir H, Bilal M, Qamar H, Mehmood Z. (2016) „In vitro evaluation of synergistic

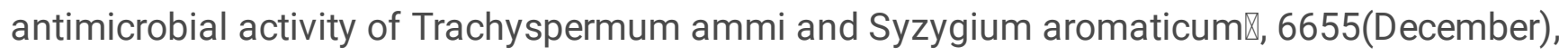
pp. 221-228.

14. Mousa OY, Dhamoon MS, Lander S, Dhamoon AS. The MD blues: under-recognized depression and anxiety in medical trainees. PloS one. 2016;11(6):e0156554.

15. Müller M, Pape HC, Speckmann EJ, Gorji A. (2006). Effect of eugenol on spreading depression and epileptiform discharges in rat neocortical and hippocampal tissues. Neuroscience, 140(2), 743-751. (Müller et al., 2006).

16. Nejad SM, ÖZGÜNEŞ H, BAŞARAN N. Pharmacological and toxicological properties of eugenol. Turk J Pharm Sci. 2017;14:201-6.

17. Nikfarjam M, Bahmani M, Heidari-Soureshjani S. Phytotherapy for anxiety in Iran: A review of the most important anti-anxiety medicinal plants. Journal of Chemical Pharmaceutical Sciences. 2016;9(3):1235-41.

18. obinson J, Sareen J, Cox BJ, Bolton JM. Role of selfmedication in the development of comorbid anxiety and substance use disorders: a longitudinal investigation. Arch Gen Psychiatry. 2011;68(8):800-7.

19. Parsaei P, Bahmani M, Karimi M, Naghdi N, Asadi-Samani M, RafieianKopaei M. A review of analgesic medicinal plants in Iran. Der Pharm Lettre. 2016;8(2):43-51.

20. Phillips RG, LeDoux JE. Differential contribution of amygdala and hippocampus to cued and contextual fear conditioning. Behavioral neuroscience. 1992;106(2):274. 
21. Siyal FJ, Memon Z, Siddiqui RA, Aslam Z, Nisar U, Imad R, Shah MR. (2020). Eugenol and liposomebased nanocarriers loaded with eugenol protect against anxiolytic disorder via down regulation of neurokinin-1 receptors in mice. Pakistan Journal of Pharmaceutical Sciences, 33.

22. Stein, M. B., Roy-Byrne, P. P., Craske, M. G., Bystritsky, A., Sullivan, G., Pyne,J. M., ... Sherbourne, C. D. (2005). Functional impact and health 141 utility of anxiety disorders in primary care outpatients. Medical care, 1164- 1170.

\section{Figures}

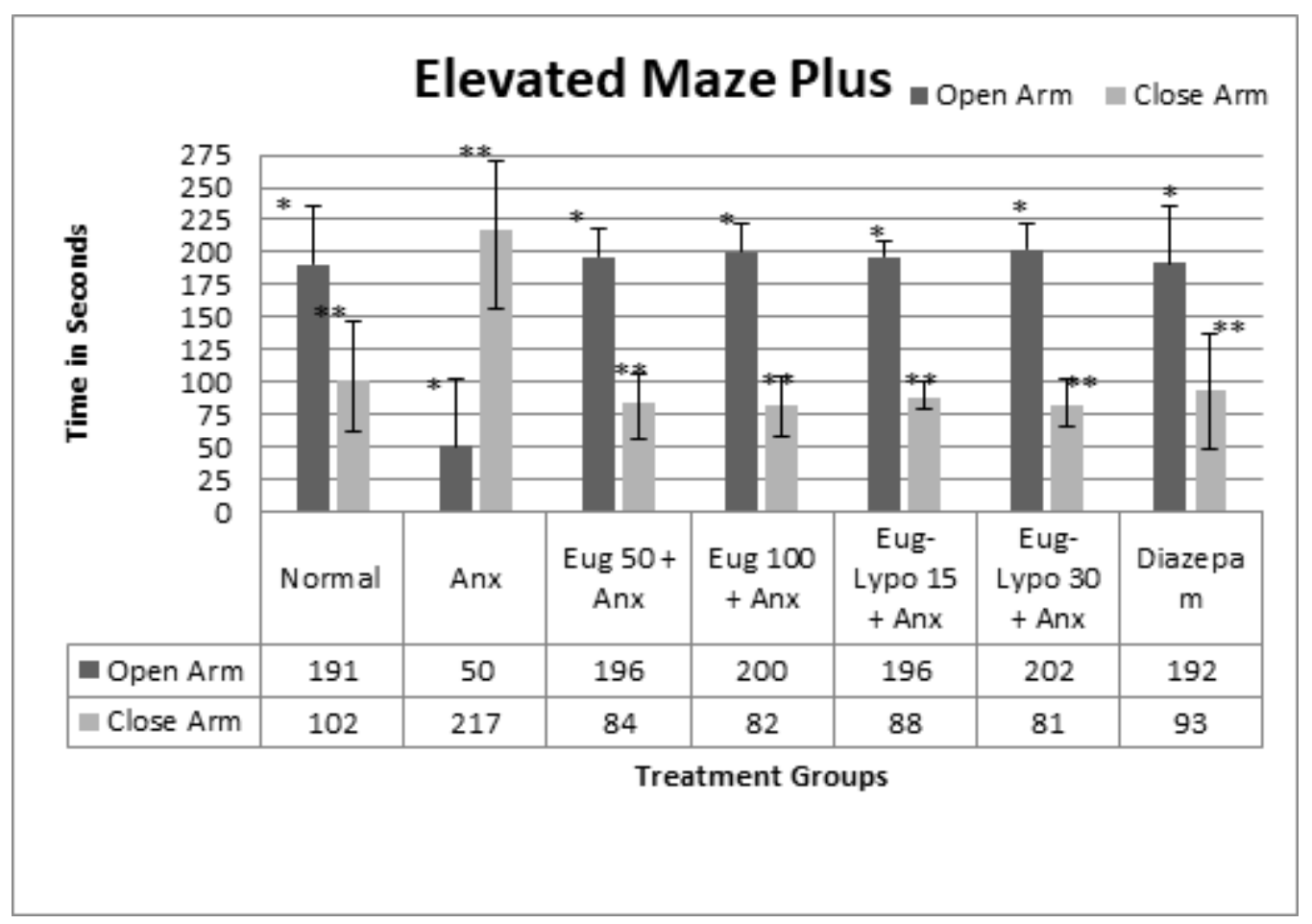

\section{Figure 1}

Elevated Plus Maze test representing values in seconds regarding mice traveled in open arm and close arm. * Representing statistical significance in open arm with paired t-test in open filed. (Anxiety group was compared with normal and treated group were compared with Anxiety groups). ** Representing statistical significance in close arm with paired t-test in open field. (Anxiety group was compared with normal and treated group were compared with Anxiety groups). 


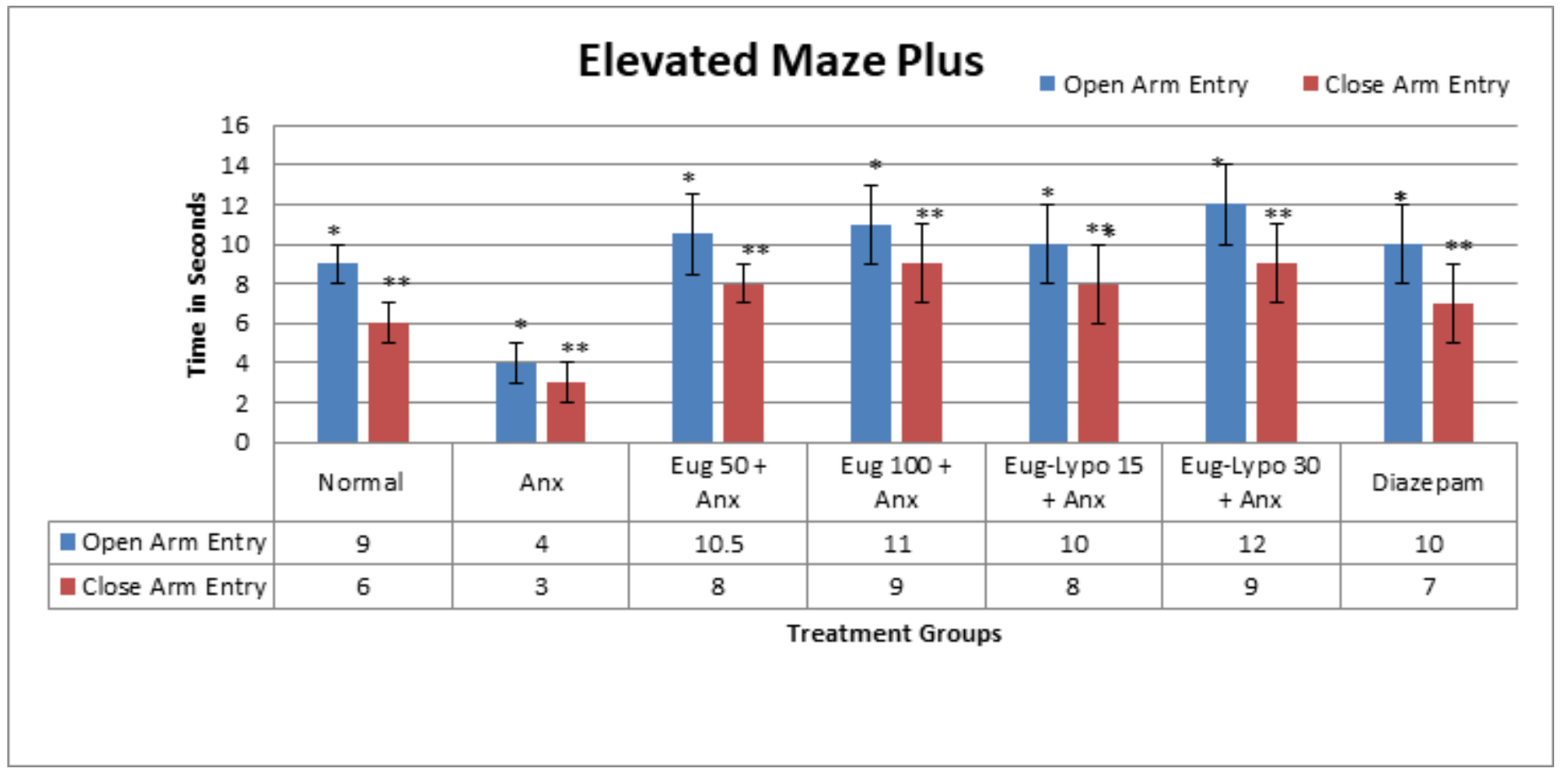

Figure 2

Elevated Plus Maze test representing entries by mice in open arm and close arm. * Representing statistical significance in open arm with paired t-test (Anxiety group was compared with normal and treated group were compared with Anxiety groups). ** Representing statistical significance in close arm with paired t-test (Anxiety group was compared with normal and treated group were compared with Anxiety groups).

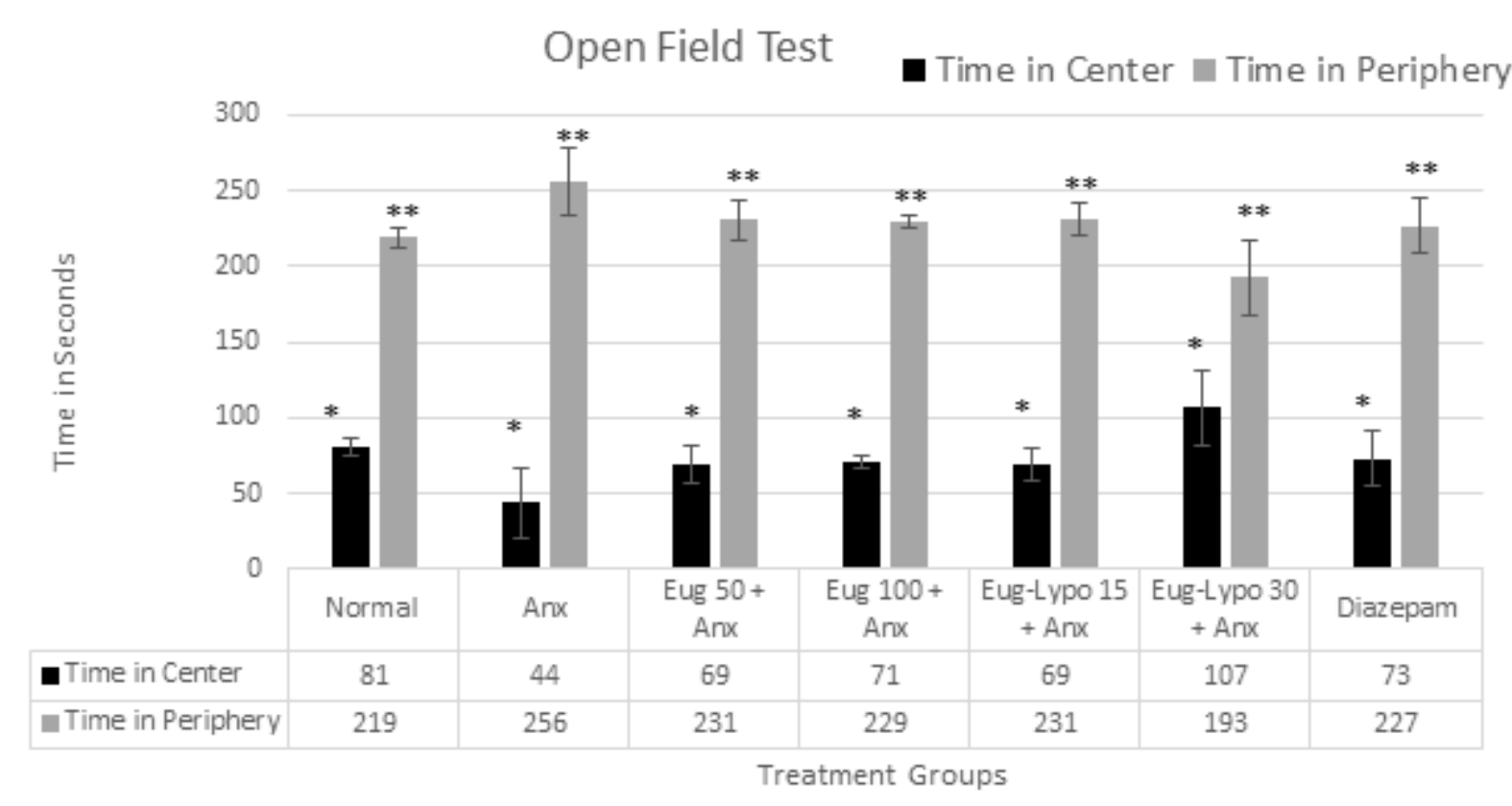

Figure 3 
Open field test representing values in seconds regarding mice traveled in centre and periphery. * Representing statistical significance in time in centre with paired t-test (Anxiety group was compared with normal and treated group were compared with Anxiety groups). ${ }^{* \star}$ Representing statistical significance in time in periphery with paired t-test (Anxiety group was compared with normal and treated group were compared with Anxiety groups). 